\title{
La Corona de Aragón en España e Italia. Un modelo común de transformación de torres musulmanas y normandas
}

\author{
Ignacio Cabodevilla-Artieda \\ Luis Agustín Hernández \\ Aurelio Vallespín Muniesa
}

Abstract

El levante español y el sur de Italia volvieron a compartir una relación política a partir del siglo XIII tras la mantenida durante siglos dentro del Imperio Romano. Las tradiciones y técnicas constructivas compartidas, así como los condicionantes climáticos y geográficos conformaron un modelo de actuación sobre las fortalezas rurales y urbanas surgidas de las invasiones normanda y musulmana. En esta comunicación se estudian varios ejemplos, tanto españoles como italianos, que confirman un planteamiento similar en las intervenciones de ampliación y mejora de estos castillos y torres para su adecuación a las necesidades del momento o su transformación en residencias nobiliarias o reales.

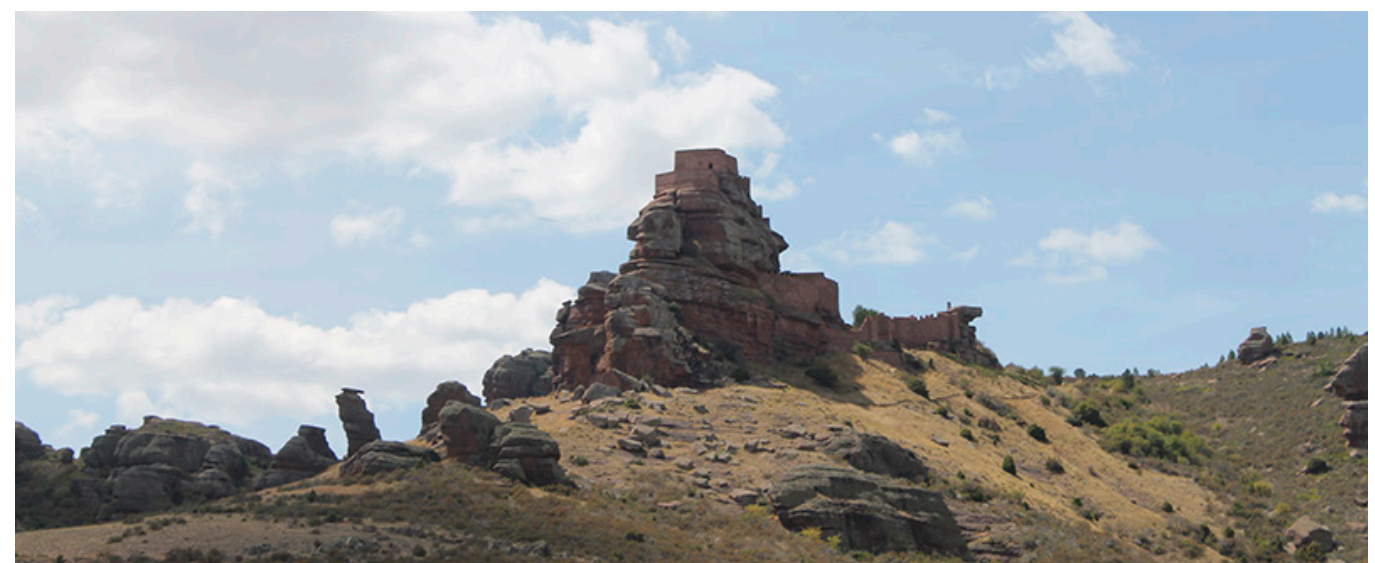




\section{Los sistemas defensivos del siglo XIII en España}

La arquitectura defensiva del siglo XIII y principios del XIV en España e Italia, fuera del ámbito urbano, se basaba en sistemas de torres de vigilancia, habitualmente de origen musulmán o normando en cada uno de los dos países, de planta rectangular o circular y en castillos roqueros plenamente medievales como el de Loarre o el Arechi de Salerno, ubicados de manera orgánica sobre una montaña y mimetizados con su entorno.

La teoría defensiva en que se basaban estas fortalezas era la de la defensa 'piombante' [I] en la que además de los proyectiles lanzados con arco o ballesta, cualquier objeto pesado puede convertirse en arma al ser arrojado desde lo alto de las defensas. Esta teoría rigió el arte de la guerra durante toda la Edad Media hasta el desarrollo de los métodos de defensa 'radente' [2] durante el Renacimiento, que supusieron una revolución en la concepción y desarrollo de la guerra así como del diseño y construcción de fortalezas.

La civilización romana fue eminentemente urbana y las legiones creaban y transportaban sus propios campamentos, por lo que no fueron habituales las fortalezas de pequeña dimensión para controlar un territorio. Esta tradición común a España e Italia de murallas urbanas o castillos junto a las poblaciones se quebró durante la Edad Media, dando lugar a la creación de pequeños fuertes que funcionaban como punto de control de una zona geográfica relativamente limitada, atendidos por reducidas guarniciones permanentes. Así, en los siglos XI y XII ya existía una extensa red de torres y casas fuertes al servicio de los señores de las zonas que les eran encomendadas, a partir de las que se produjo un modelo de crecimiento orgánico, que reutilizaba los elementos anteriores o los desechaba en función de su calidad constructiva o estado de conservación, que presenta características similares entre los territorios españoles e italianos de la Corona de Aragón.

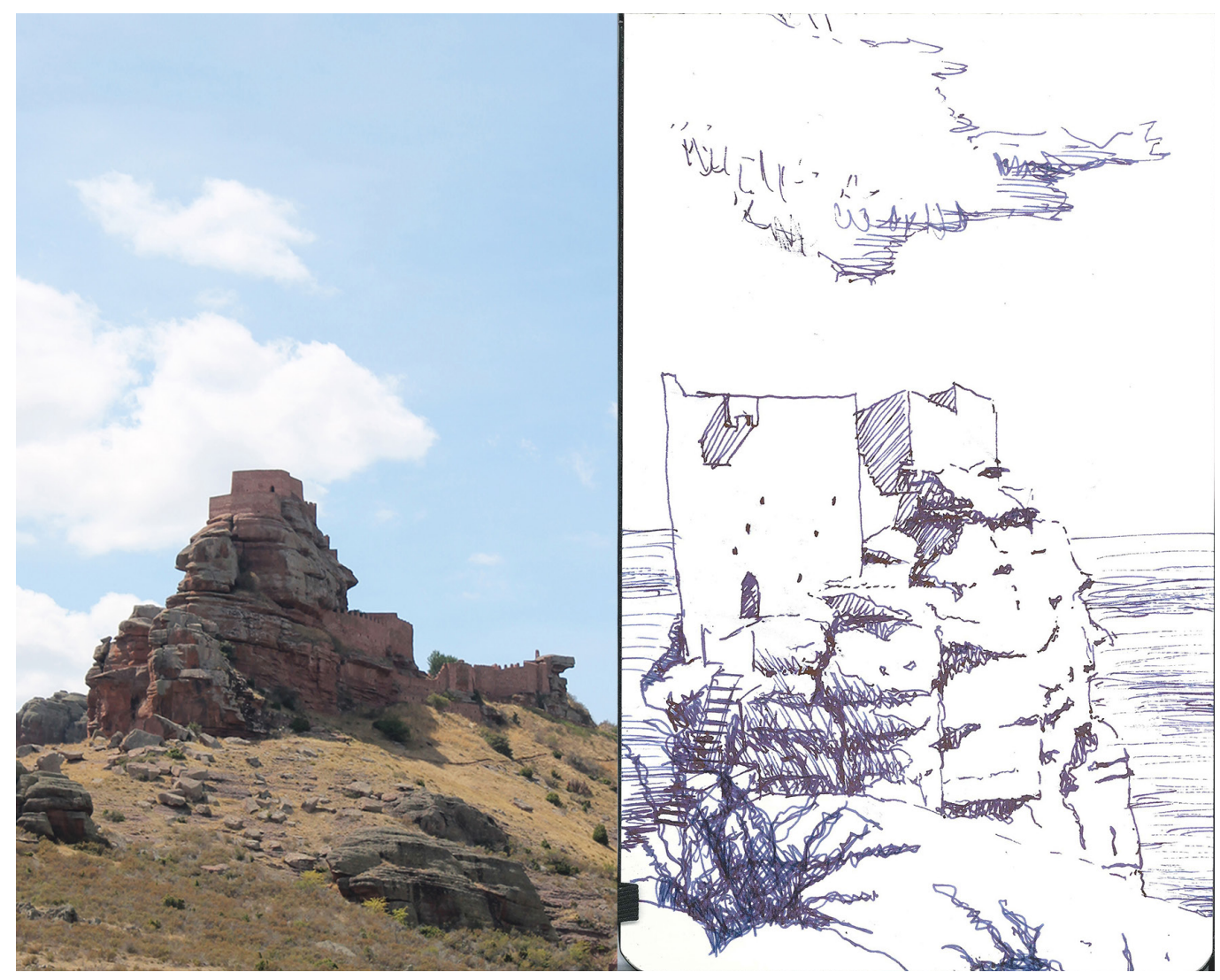




\section{El castillo de Peracense (Aragón, España)}

El castillo de Peracense se encuentra situado en el eje norte-sur de la Sierra Menera, a una altitud de unos I 365 metros sobre el nivel del mar, dominando desde la misma el extenso valle del río jiloca que se extiende hacia el este y el valle del río Gallo al oeste.

Su origen se remonta a la construcción de una pequeña torre por parte de los musulmanes para controlar ambos valles desde una única posición. Este elemento inicial se levantaba sobre un gran espolón rocoso de rodeno que corona unas pendientes relativamente suaves tanto hacia el este como hacia el oeste. De este elemento inicial no quedan restos, más allá de las evidencias arqueológicas que confirman su existencia durante los siglos X y XI.

Con el avance hacia el sur del reino de Aragón, el castillo de Peracense se convirtió en parte del sistema defensivo de la Taifa y posterior Señorío de Albarracín, para ser finalmente reutilizada por Pedro III de Aragón como base de las operaciones para su conquista y definitiva anexión a Aragón en I284 [Zueco Giménez 20 I I].

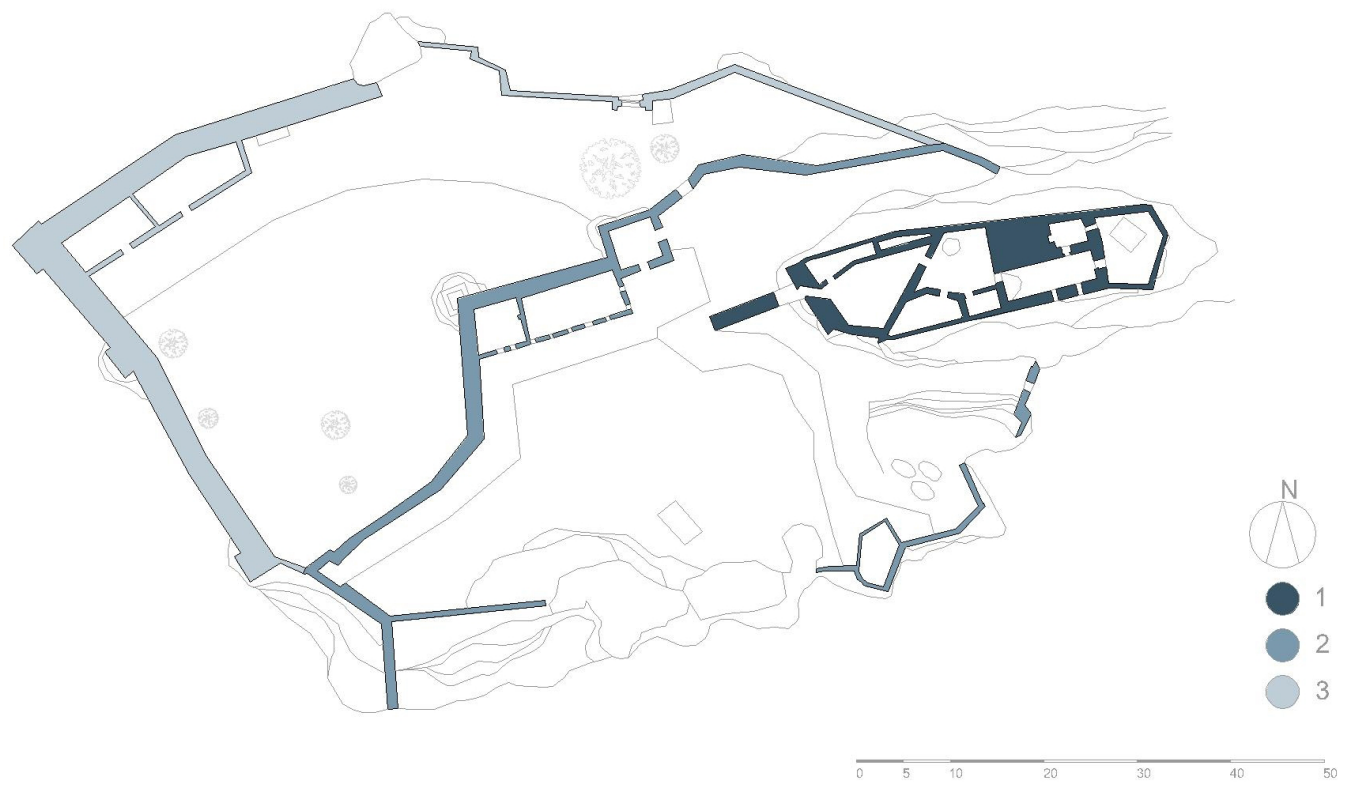

De esta época data el recinto interior y más elevado de la fortaleza, enclavado sobre una gran roca que surge del terreno, donde se situaba la torre de origen musulmán. El acceso a este elemento se produce actualmente a través de una escalera fija que salva el desnivel de unos cuatro metros que separa el nivel del terreno y el de la roca, pero originalmente, este acceso de producía a través de una escalera móvil que se retiraba en caso de ataque enemigo. El interior se compone de dos espacios cerrados, la torre del acceso y la equivocadamente denominada torre del homenaje, separados por un patio central amurallado. La puerta de acceso se protege con matacanes sobre la misma en la coronación del muro y el resto de lienzo de muralla se corona con almenas, aunque de construcción muy posterior en diversas intervenciones restauradoras llevadas a cabo durante el siglo XX.

Debido a su posición elevada sobre dos valles relativamente amplios y llanos, la Sierra Menera se convirtió en un enclave fundamental para el control de la frontera entre los reinos de Aragón y Castilla durante toda la Edad Media. Esta circunstancia fue aprovechada por los aragoneses para reforzar y ampliar el castillo de Peracense y construir una serie de fortificaciones a lo largo de toda la sierra, destacando entre ellas los castillos de Ares, Ródenas y Alba, que dominaban las vías de acceso desde Castilla y tuvieron un papel protagonista durante la Guerra de los dos Pedros entre los años 1356 y 1369. 
El trazado básico del castillo de Peracense que ha llegado hasta hoy se produjo en el siglo XIV [Guitart Aparicio 1999], y se llevó a cabo, al igual que los elementos del primer recinto, con sillares y mampostería de material extraído de la misma roca sobre la que se asienta, lo que le otorga su característico color rojizo y provoca su mimetismo con el entorno y su camuflaje visual desde cierta distancia.

El segundo recinto está cerrado por una muralla discontinua que desaparece en las secciones en que la pendiente del terreno y la presencia de rocas de grandes dimensiones la hace innecesaria. Este perímetro está reforzado por dos torres de planta rectangular que protegen el pequeño edificio adosado al lienzo de la muralla y cubierto con una bóveda de crucería a través del que se produce el acceso.

Al recinto exterior se accede a través de una rampa zigzagueante, que permite una entrada directa al patio de armas exterior, situado en el nivel más bajo del terreno. La muralla que lo cierra completa secciones de la segunda y amplía hacia el oeste la planta de la fortaleza; se mantienen en pie tres torres de planta rectangular, situadas en los encuentros entre las diversas fases de desarrollo de las murallas y en el extremo oeste de la ampliación.

Quedan pocos restos de los edificios que contenía el castillo, pero sí se puede afirmar la utilización de cubiertas con arcos diafragma por la presencia de algunos de ellos, sin su correspondiente cubierta, sobre el aljibe, y cubiertas con bóvedas de cañón apuntadas y reforzadas por arcos fajones. Los muros están construidos en su totalidad con mampostería y fábrica de sillería de rodeno.

El conjunto resulta una planta irregular, orgánica, adaptada a las irregularidades del terreno como corresponde a un castillo roquero desarrollado en diversas fases, por señores y reinos distintos, y con una función fundamental de control del territorio.

Una vez perdida su utilidad como castillo fronterizo con Castilla fue entregado a la Comunidad de Aldeas de Daroca que lo transformó en cárcel y abandonó posteriormente; durante las guerras Carlistas fue utilizado por ambos bandos alternativamente y posteriormente abandonado. A partir de 1987 se han realizado diversas campañas arqueológicas y restauraciones del conjunto, incluyendo repristinaciones de secciones completas de las murallas.

\section{Otros casos de estudio en el límite entre Castilla y Aragón (España)}

Los límites territoriales entre Aragón y Castilla sufrieron constantes situaciones bélicas a lo largo del siglo XIV, por lo que desde ambos lados se construyeron nuevas fortalezas y mejoraron las existentes siguiendo un mismo modelo. Generalmente se partió de elementos anteriores, como se ha detallado en el caso de Peracense, reforzando lo construido o eliminándolo en casos de deficiente construcción o estado de conservación para mantener la posición anterior, ya que el escaso desarrollo de las técnicas y teorías bélicas durante el período medieval anterior al Renacimiento no cambió durante siglos las necesidades a satisfacer por la localización de las torres o castillos.

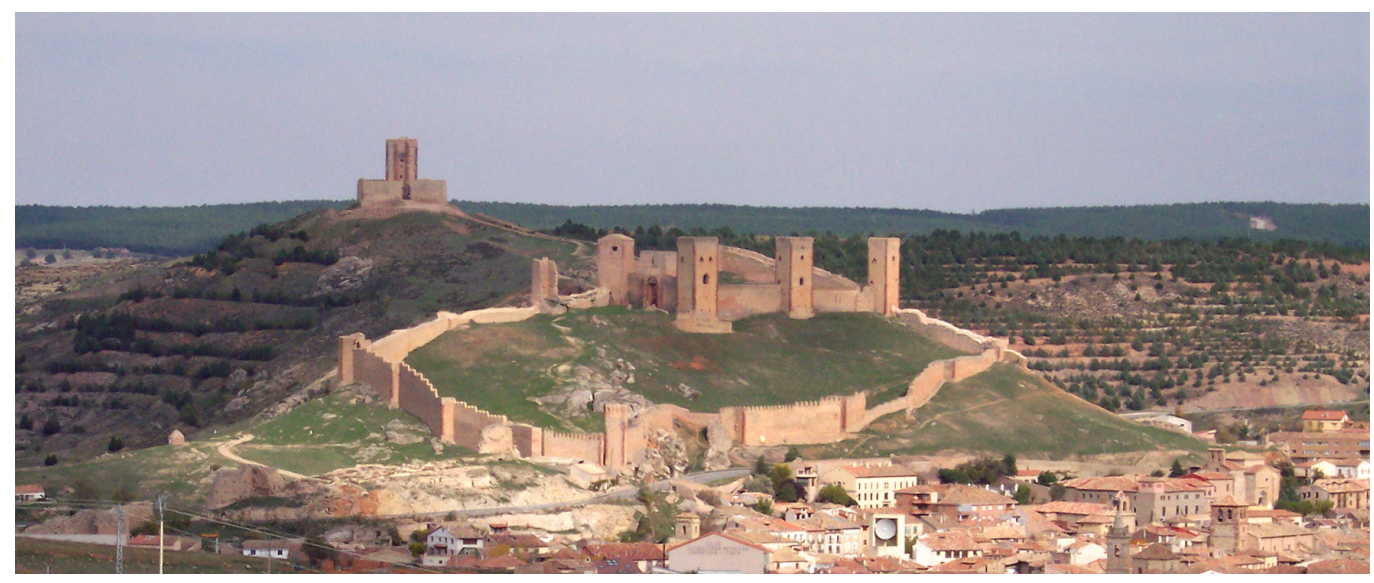


En el lado castellano, son destacables los casos de los castillos de Zafra y Molina de Aragón, ambos en la actual provincia de Guadalajara. Partiendo de torres de origen musulmán se desarrollaron fortalezas con diversos anillos que envolvín los elementos anteriores con un sistema de crecimiento orgánico adaptado al relieve de los cerros en los que se implantaban. El castillo de Molina de Aragón destaca por las grandes dimensiones del recinto exterior, con un perímetro aproximado de 800 metros, que se extiende por la pendiente de la montaña hasta la población que se sitúa a sus pies. Contaba con cinco puertas de acceso y ocho torres de planta rectangular como refuerzo de los muros [Herrera Casado 1999]. Como en el caso de Peracense, se han repristinado secciones enteras de las murallas, permitiendo entender el edificio en su conjunto.

El castillo de Zafra se sitúa en la Sierra de Caldereros, en la prolongación hacia el oeste de la Sierra Menera, por lo que presenta unas condiciones geológicas y topográficas muy similares a ésta. De dimensiones menores que el castillo de Peracense, el de Zafra se limita al desarrollo sobre una gran roca de rodeno que aflora sobre una pequeña colina a partir de un torreón inicial en el extremo norte, extendiéndose posteriormente hacia el sur una muralla que encierra un pequeño patio de armas que se cierra en su extremo con una torre de grandes dimensiones y planta cuadrada. La imagen de este castillo puede llegar a ser indistinguible de la del de Peracense, enclavados sobre rocas similares y edificados con las mismas técnicas constructivas y materiales.

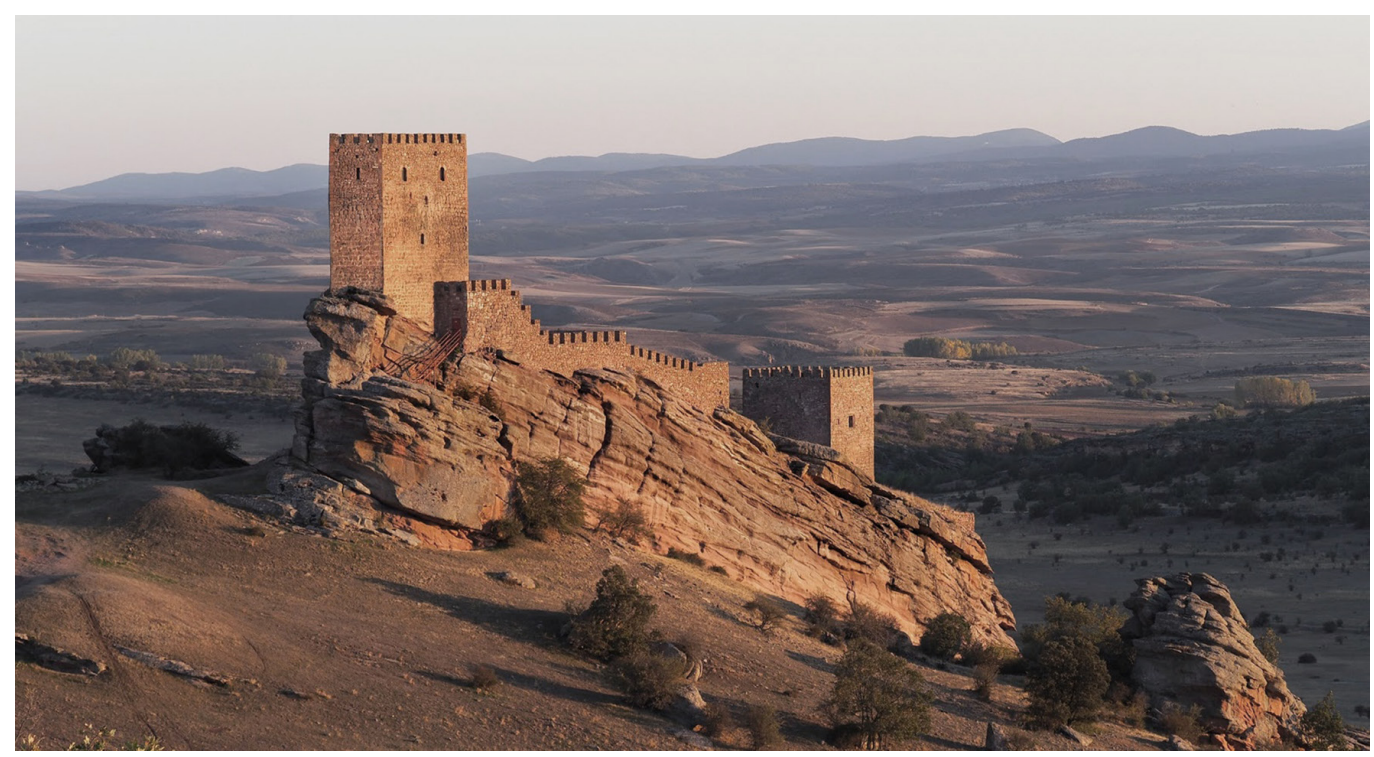

\section{El palacio de la Aljafería (Aragón, España)}

El palacio de la Aljafería parte de una torre musulmana del siglo IX y sus graduales ampliaciones para servir como residencia de los reyes de la Taifa de Zaragoza hasta el siglo XII.Tras la conquista cristiana de la ciudad por parte de Alfonso I el Batallador en I I I 8, se convirtió en residencia de los reyes de Aragón y sufrió sucesivas intervenciones y ampliaciones, siendo las más importantes las ejecutadas bajo el reinado de Pedro IV el Ceremonioso y los Reyes Católicos.

Adosada a la muralla noroeste, Pedro IV construyó la capilla de San Martín entre los años I 338 y I 339 utilizando sistemas tradicionales de cubiertas con bóvedas de crucería, y concluyó la arquería occidental del patio de Santa Isabel con arcos apuntados polilobulados. El mayor hallazgo técnico de esta ampliación no se conserva, pero significó la introducción 
Fig. 6. Vista del acceso al mihrab del palacio de la Aljafería desde el patio de Santa Isabel (autor: Luis Agustín Hernández).

Fig. 7. Esquema de la evolución y fases constructivas del palacio de la Aljafería (autor: Ignacio CabodevillaArtieda).

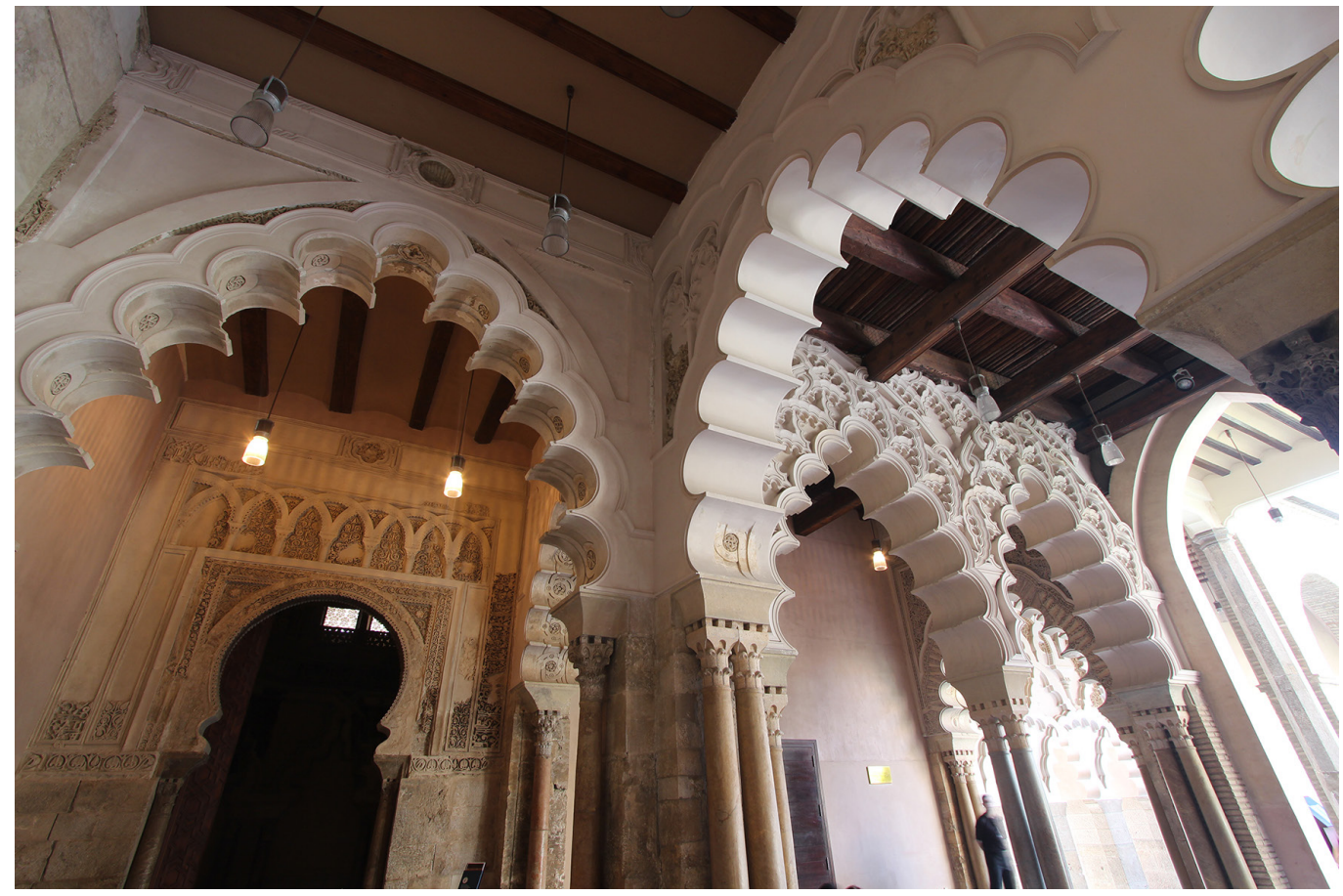

de la bóveda tabicada en Aragón, al ser utilizada para cubrir el espacio de la nueva capilla de San Jorge [Zaragozá Catalán e Ibáñez Fernández 20I I].

Los Reyes Católicos añadieron una nueva planta a la sección norte del palacio a la que se accede a través de una escalera monumental, mezclando motivos decorativos de inspiración musulmana con grutescos y un delicado artesonado en el Salón del Trono que anuncian la llegada del Renacimiento. Las últimas fases reproducen los diseños que realizó Tiburzio Spannocchi para su adecuación a los nuevos sistemas de artillería y que nunca llevó a cabo, siendo estas actuaciones muy posteriores en el tiempo y realizadas con un afán historicista. En conjunto, es una mezcla de residencia real y castillo que aúna las características organizativas y decorativas del mundo musulmán con el cristiano medieval y los inicios del Renacimiento.

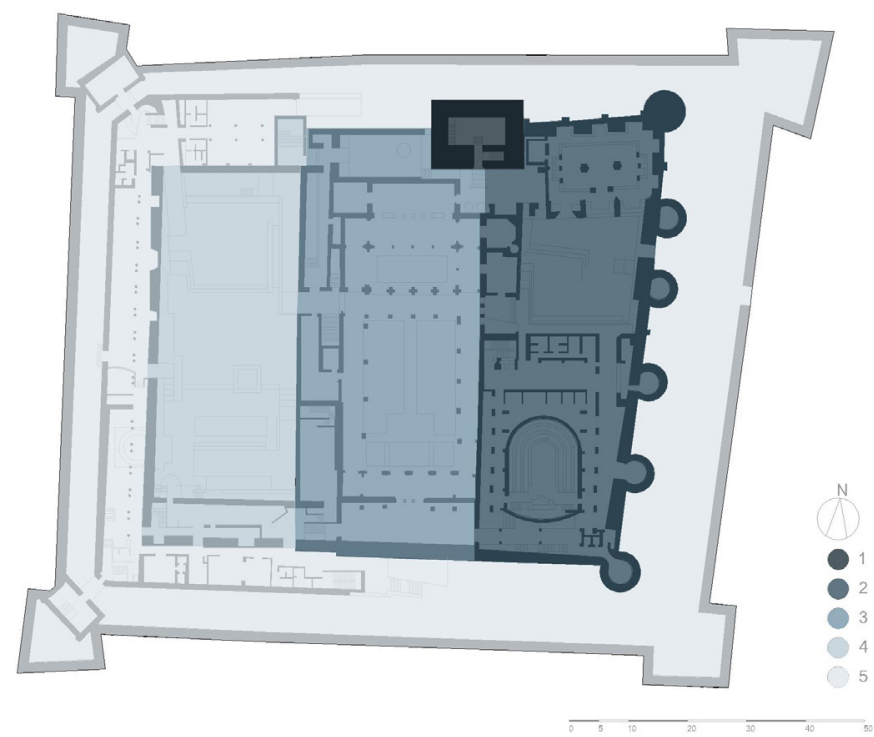




\section{Castel Lagopesole (Basilicata, Italia)}

El caso del castillo de Lagopesole presenta grandes similitudes con el de la Aljafería en cuanto su origen y desarrollo. Algunas teorías sitúan el origen del castillo en una fortaleza de fundación musulmana [Peduto, Santoro 2006], pero los restos más antiguos que se conservan corresponden a algunas estructuras murarias, descubiertas en distintas excavaciones arqueológicas, pertenecientes a una pequeña fortaleza de los siglos $X$ y $X \mathrm{I}$, cuando la zona pertenecía al principado longobardo de Salerno [Fiorillo 20l I], y al donjón de época normanda. El impulso a la construcción del castillo actual es de época federiciana, en la que se amplió el recinto amurallado [lorio 2007], aunque apenas se conoce nada sobre los elementos que componían la fortaleza durante esta fase.

La configuración actual del castillo se debe a los trabajos de época angevina, a caballo entre los siglos XIII y XIV [Rescio 1998]. La planta del conjunto es rectangular (de aproximadamente $94 \times 53$ metros), reforzado por torres de planta cuadrada en las esquinas, dos torres protegiendo la entrada principal y una más que proyecta el ábside de la capilla hacia el exterior. Los muros son rectos, de altura uniforme en todo el recinto y la parte superior no está almenada, confirmando su función a medio camino entre castillo y residencia real. En su interior hay dos patios, correspondientes a dos fases constructivas consecutivas. El primero y de menor tamaño alberga la torre normanda, exenta y desalineada con el resto de la construcción, y dependencias en uno solo de sus laterales; el segundo acoge

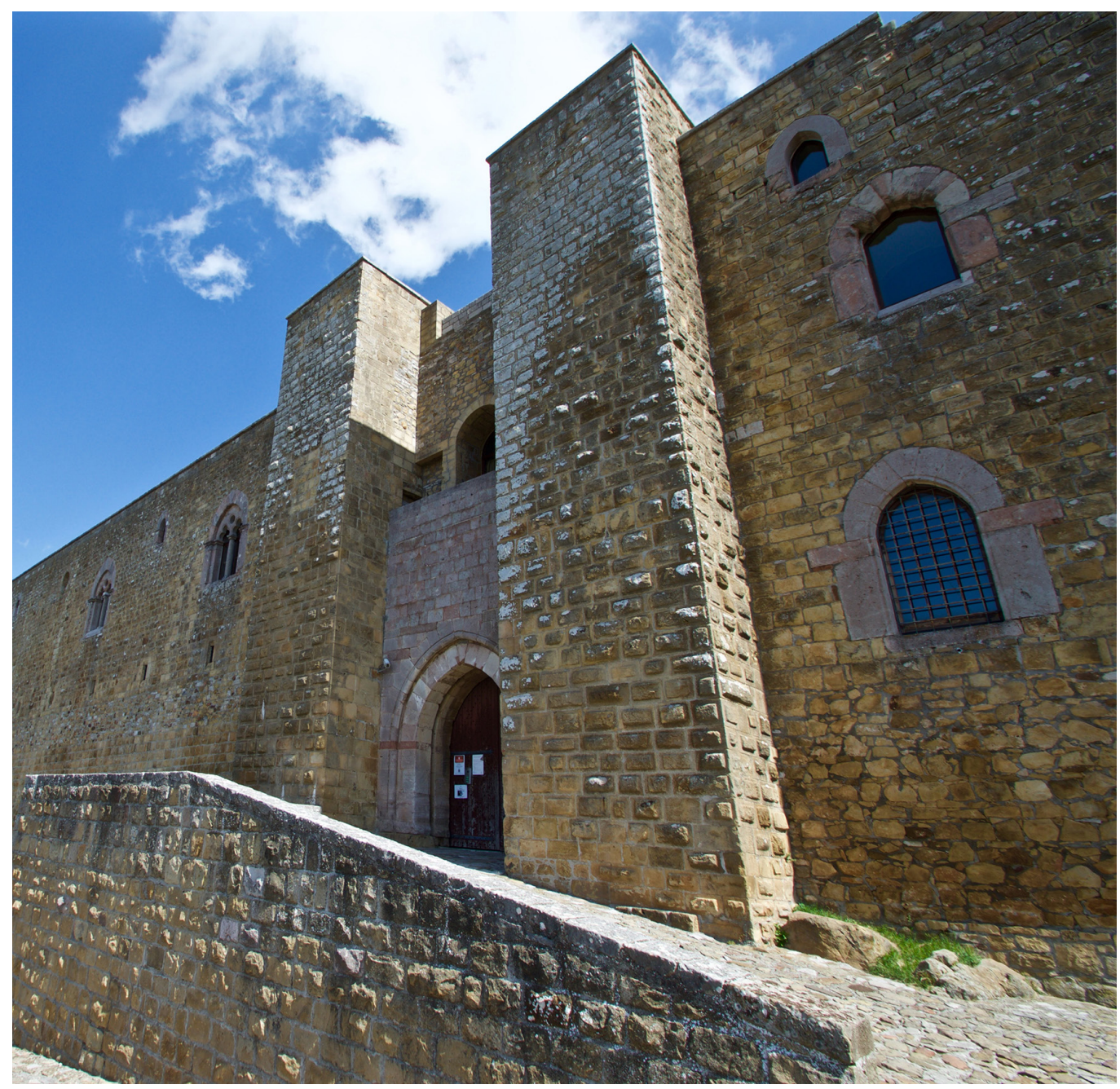


la escalera descubierta para acceder a la planta superior, el acceso a la capilla y diferentes espacios cubiertos en los tres lados exteriores. El último elemento añadido al conjunto, en época aragonesa, es el rebotadero construido en la torre noroeste, interrumpiéndose posteriormente la adecuación del conjunto al equipamiento de una fortaleza 'a la moderna'. La imagen que ofrece el conjunto en la actualidad está distorsionada por la colmatación del foso que circundaba el castillo y la extracción de piedra para la construcción en pleno siglo $X X$.

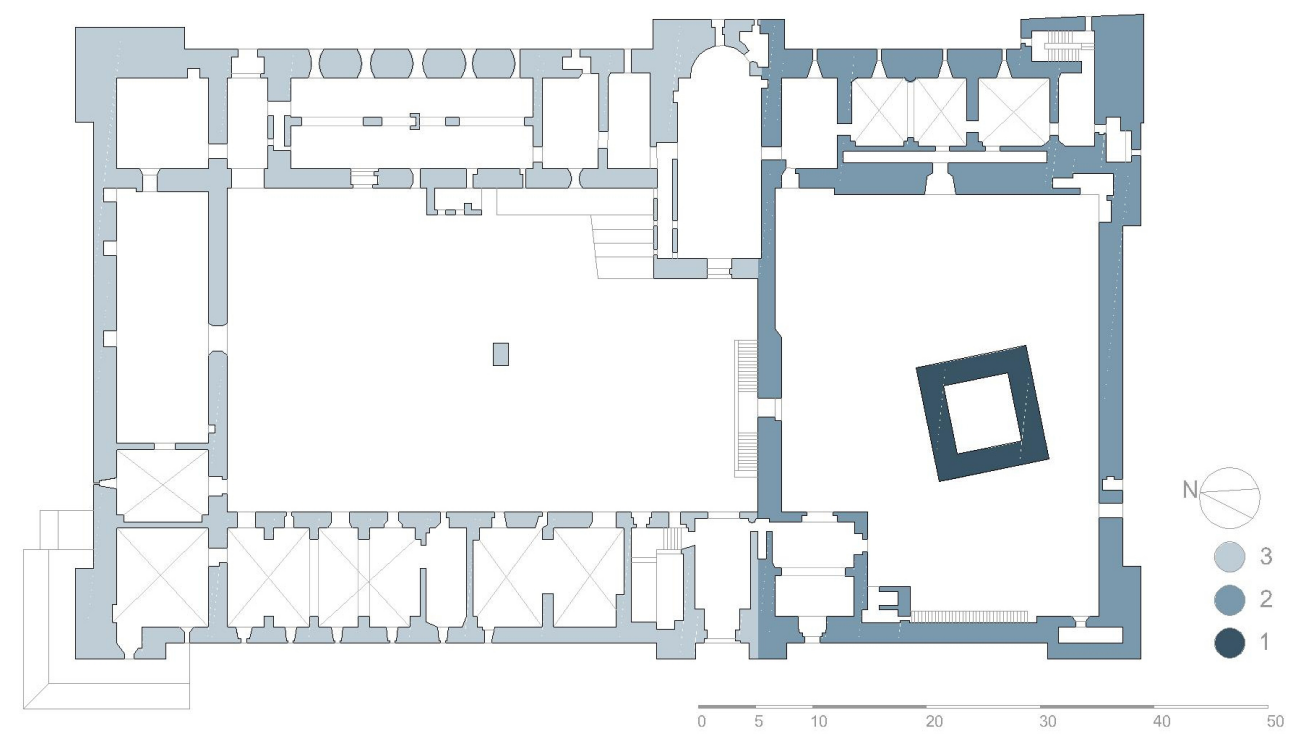

\section{Otros casos en los territorios italianos de la Corona de Aragón}

El mismo origen y proceso de desarrollo del castillo de Lagopesole caracteriza a múltiples fortalezas del sur de Italia. Paradigmático es el caso del castillo Ducale de Ceglie Messapica (Apulia), cuyo elemento más antiguo es la base de la torre de planta cuadrada, construida por los normandos, sobre la que se levantan las ampliaciones angevinas y aragonesas de los siglos XIII y XIV, alcanzando una altura total de 34 metros [V.AA 2006]. La planta del conjunto es irregular, adaptándose al terreno sobre el que se asienta, con las tres esquinas principales reforzadas por torreones de planta circular construidos en tres pisos claramente diferenciados; una base troncocónica de poca altura, un segmento central cilíndrico separado de la base por una cornisa tórica, y una coronación volada sobre el cuerpo inferior y apoyada sobre unas ménsulas.

En conjunto nos encontramos ante un claro ejemplo de fortaleza de concepción y desarrollo medieval, típica de los castillos feudales de la zona, con una posición defensiva elevada o piombante sobre el enemigo debido a la cota de los muros y la situación del conjunto en el punto más alto de la población en un momento en el que el escaso desarrollo de la artillería todavía no exigía una concepción 'a la moderna'.

Similar desarrollo siguieron los castillos de Santa Severina (Calabria) y Monte Sant'Angelo (Apulia), añadiendo un capítulo final de adaptación a la poliorcética moderna, incorporando bastiones, foso y puntos para el disparo con armas de fuego. 


\section{Conclusiones}

El desarrollo de las fortalezas en el ámbito español e italiano de la Corona de Aragón durante los siglos XIII, XIV y XV siguió caminos paralelos. En ambos territorios se partía de un pasado romano que dotaba de gran importancia al ámbito urbano dentro de una organización fuertemente centralizada que entró en crisis en la Edad Media y fue atomizada por importantes influencias extranjeras, ya fueran éstas de normandos o francos que acudían a luchar contra las invasiones musulmanas o las de los propios musulmanes, presentes en la península ibérica durante siglos. Los elementos creados por musulmanes y normandos para control del territorio fueron posteriormente utilizados, reformados y ampliados siguiendo criterios y sistemas similares, recuperando tradiciones constructivas comunes, y siendo posteriormente abandonados cuando las zonas de conflicto se alejaban o transformándose en residencias palaciegas al perder su sentido militar.

\section{Notes}

[I] Es un sistema defensivo típico de la época de las armas blancas, consistente en el lanzamiento de proyectiles sólidos o líquidos (flechas, piedras, aceite, brea...) sobre los asaltantes; esto sólo era posible desde una posición elevada, bien debido a la propia localización del castillo sobre una colina o montaña, bien por la altura de los muros de la fortaleza.

[2] Sistema defensivo que incorpora la pólvora, mediante el lanzamiento de proyectiles con armas de fuego.

\section{Referencias}

Fiorillo Rosa (20 I I). Castel Lagopesole (PZ): l'ammodernamento angioino del castrum normanno. In Paolo Peduto, Alfredo Maria Santoro (a cura di). Archeologia dei castelli nell'Europa angioina (secoli XIII-XV) (Salerno, 2008). Firenze: All'Insegna del Giglio, pp. 26-30.

Guitart Aparicio Cristóbal (1999). Castillos de Aragón. Zaragoza: Caja de Ahorros de la Inmaculada de Aragón.

Herrera Casado Antonio (1999). Guía de Campo de los Castillos de Guadalajara. Guadalajara: Ediciones AACHE.

Iorio Guido (2007). I/ Giglio e la Spada. Istituzioni e strutture militari nel meridione angioino. Rimini: il Cerchio Iniziative Editoriali.

Peduto Paolo, Santoro Alfredo Maria (2006). II castello di Lagopesole in Basilicata: analisi di alcune strutture del castrum altomedievale e della Domus federiciana. In Francovich Riccardo, Valenti Marco (a cura di). Società degli Archeologi Medievalisti Italiani. IV Congresso Nazionale di Archeologia Medievale. Chiusdino 26-30 settembre, 2006. Firenze: All'Insegna del Giglio, pp. $621-626$.

Rescio Pierfrancesco (1998). Archeologia e Storia dei Castelli di Basilicata e Puglia. Potenza: Consiglio Regionale di Basilicata.

W.AA. (2006). Architetture fortificate di età aragonese in Puglia. Capitanata, Terra di Bari e Terra d'Otranto. Bari: Mario Adda editore.

Zaragozá Catalán Arturo, lbáñez Fernández Javier (20I I). Materiales, técnicas y significados en torno a la arquitectura de la Corona de Aragón en tiempos del Compromiso de Caspe (|4|0-14|2). In Artigrama, n.26, pp. 21-102.

Zueco Giménez Luis (20I I). Castillos de Aragón. Zaragoza: Mira.

Autores
Ignacio Cabodevilla-Artieda, Universidad de Zaragoza. nca@unizar.es
Luis Agustín Hernández, Universidad de Zaragoza. lagustin@unizar.es
Aurelio Vallespín Muniesa, Universidad de Zaragoza. aureliov@unizar.es

Para citar este capítulo: Cabodevilla-Artieda Ignacio, Hernández Luis, Vallespín Muniesa Aurelio (2020). La Corona de Aragón en España e Italia. Un modelo común de transformación de torres musulmanas y normandas/The Crown of Aragon in Spain and Italy. A common prototype for the transformation of Islamic and Norman towers. In Arena A., Arena M., Brandolino R.G., Colistra D., Ginex G., Mediati D., Nucifora S., Raffa P. (a cura di). Connettere. Un disegno per annodare e tessere. Atti del $42^{\circ}$ Convegno Internazionale dei Docenti delle Discipline della Rappresentazione/Connecting. Drawing for weaving relationships. Proceedings of the 42th International Conference of Representation Disciplines Teachers. Milano: FrancoAngeli, pp. 957-974. 


\section{The Crown of Aragon in Spain and Italy. A Common Prototype for the Transformation of Islamic and Norman Towers}

Ignacio Cabodevilla-Artieda

Luis Agustín Hernández

Aurelio Vallespín Muniesa

\section{Abstract}

The Spanish East and southern Italy recovered their political relationship from the 13th century onwards after the one they maintained for centuries within the Roman Empire. Shared constructive traditions and techniques, as well as climate and geographical conditions gave shape to a way of transforming the rural and urban fortresses arising from the Norman and Islamic invasions. This paper explores several examples, both Spanish and Italian, which confirm a similar approach in the interventions of expansion and improvement of these castles and towers for their adaptation to the needs of the time or the transformation into noble or royal residences.

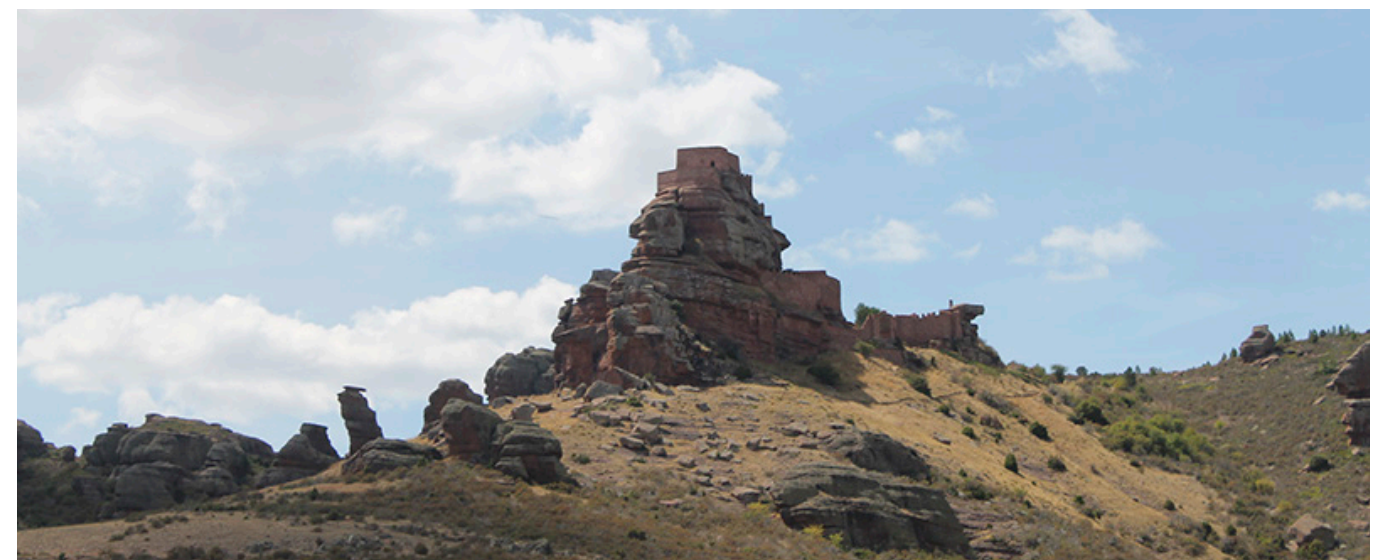




\section{The defensive systems of the 13th century in Spain}

The defensive architecture of the I3th and beginning of the 14th century, out of the urban sphere, was based upon systems of watchtowers, usually of Islamic or Norman origin in each country, square or round shaped and strictly medieval ridge castles such as Loarre or Arechi in Salerno, placed on mountaintops and completely blended with their surroundings. The defensive theory, on which these fortresses were based, was that of the 'piombante' [I] defense, in which, in addition to the arrows shot with bow or crossbow, any heavy object might become a weapon when thrown from the top of the walls. This theory ruled the art of war throughout the Middle Ages until the 'radente' [2] defensive methods were developed in the Renaissance, which meant a revolution for war and the design and construction of fortresses.

Roman civilization was eminently urban and the legions built and transported their own camps, so small fortresses for controlling a territory were not common. This tradition common to Spain and Italy of urban walls or castles next to the towns broke down during the Middle Ages, leading to the creation of small forts that functioned as a control point for a relatively limited geographical area, served by small permanent garrisons. Thus, in the IIth and I2th centuries there was already an extensive network of towers at the service of the lords of the areas that were entrusted to them, from which there was a process of organic growth, which reused the previous elements or discarded them according to their constructive quality or state of conservation. This process has similar characteristics between the Spanish and Italian territories of the Crown of Aragon.

Fig. I. View of the upper precinct of the Peracense castle from the East (author: Ignacio

Fig 2 View of the Access to the upper precinct of the Peracense castle (author: Aurelio Vallespin Muniesa).

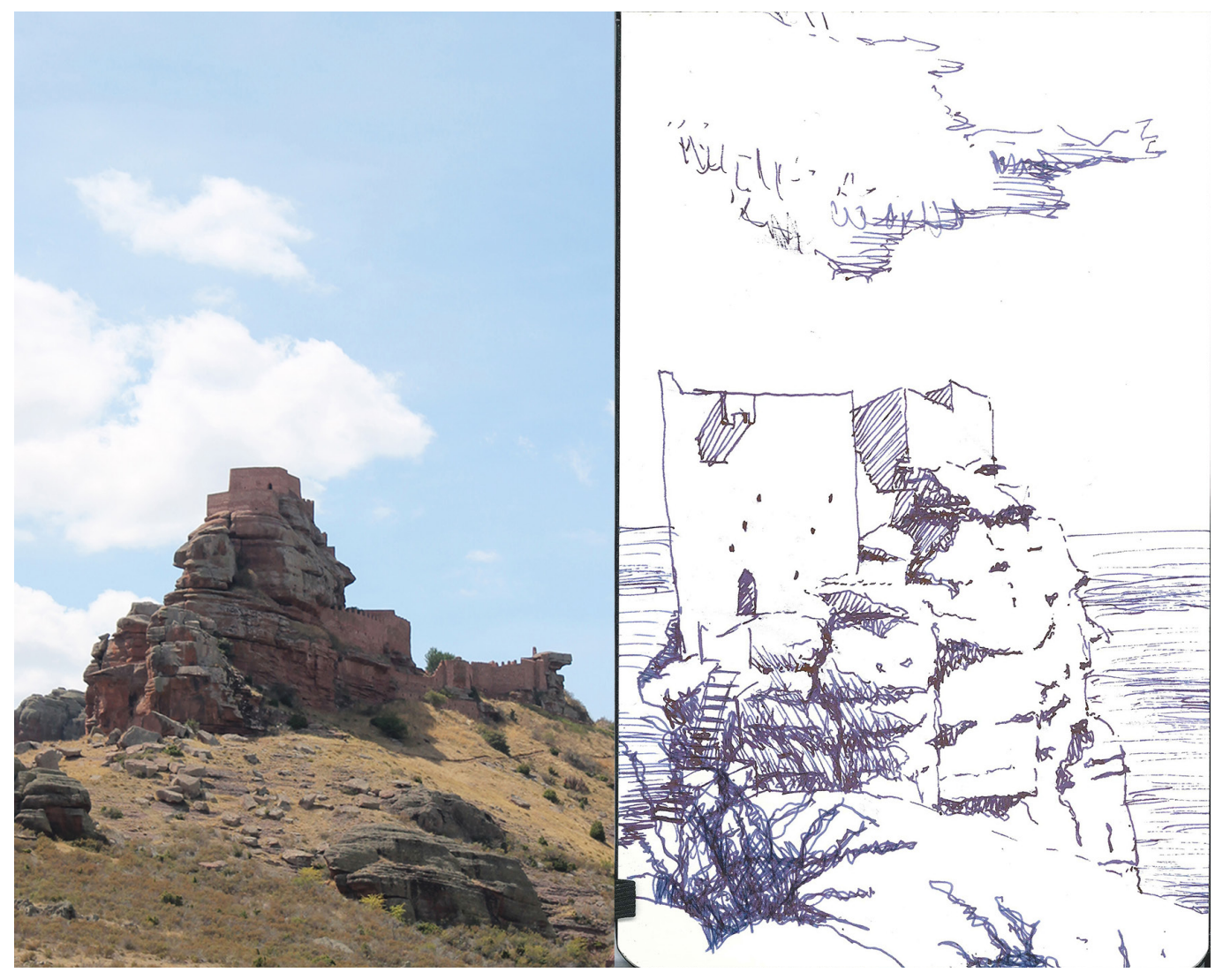




\section{The Peracense Castle (Aragon, Spain)}

The Peracense castle is located on the North to South axis of the Sierra Menera, at an altitude of about 1365 meters above sea level, from which can be seen the extensive valley of the Jiloca River that extends to the East and the valley of the Gallo River to the West. Its origin dates back to the construction of a small Islamic tower to control both valleys from a single position. This initial element rose on a large rock of rodeno with relatively gentle slopes to both the East and West. There are no remains of this initial element, other than the archaeological evidence that confirms its existence during the IOth and I Ith centuries. With the advance towards the South of the Kingdom of Aragon, the Peracense castle became part of the defensive system of the Taifa and later Señorío de Albarracín, to be finally reused by Peter III of Aragon as the military base for its conquest and definitive annexation to Aragon in 1284 [Zueco Giménez $201 \mathrm{l}$ ]. The most elevated and inner precinct of the fortress dates back to this time, and is nestled on a large rock that rises from the terrain,

Fig. 3. Evolution and constructive phases castle (author: Ignacio castle (author: Ignacio

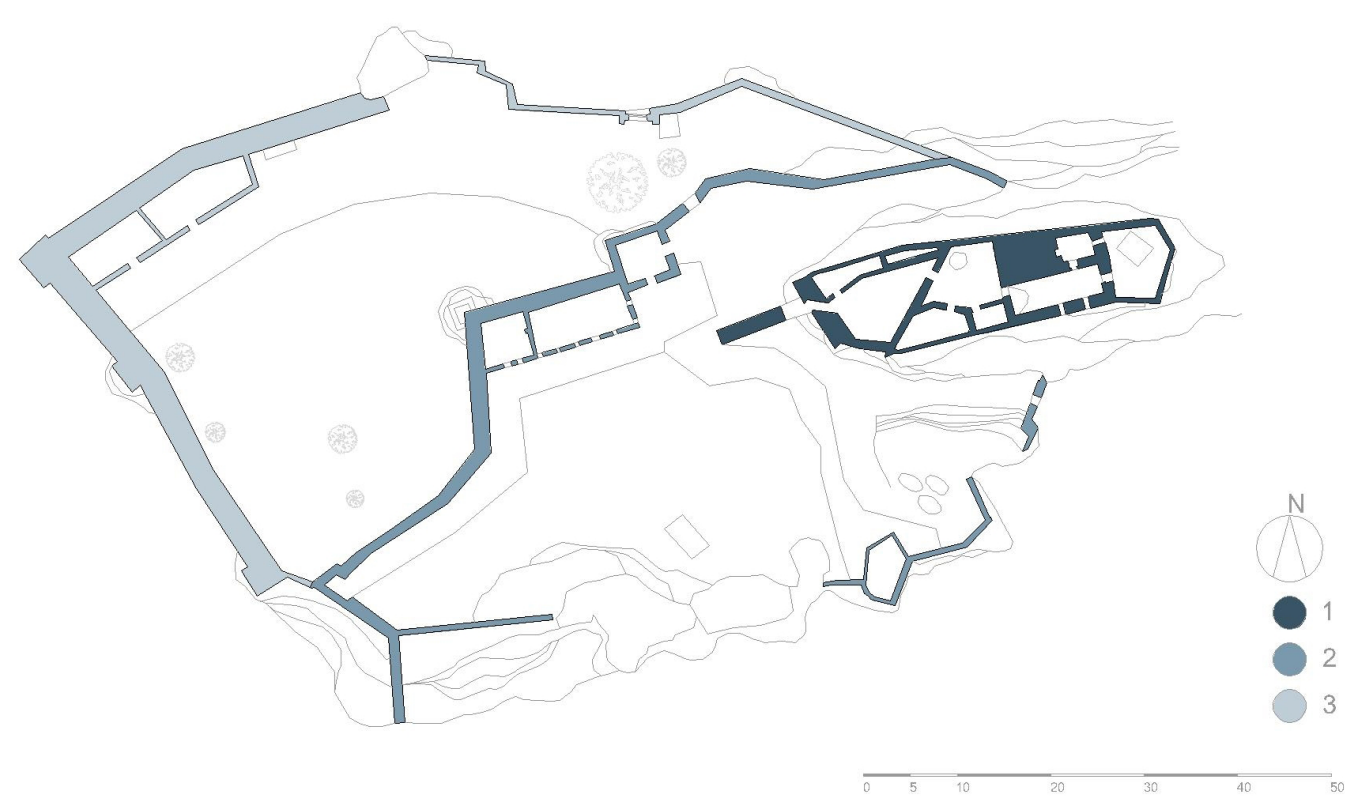

where the tower of Islamic origin was located. Access to this element is currently provided through a fixed staircase that spans for four meters, the distance that separates the level of the terrain and that of the rock. Originally, this access used a ladder that could be removed in case of an attack. The interior consists of two enclosed spaces, the entrance tower and the wrongly called keep, separated by a walled central courtyard. The access door is protected with machicolations on top of the wall while the rest of the wall is crowned with battlements, although of very later construction in various restorative interventions carried out during the 20th century.

Due to its elevated position over two relatively wide and flat valleys, the Sierra Menera became a fundamental enclave for the control of the border between the kingdoms of Aragon and Castile throughout the Middle Ages. This circumstance was used by the Aragonese to reinforce and expand the Peracense castle and build a series of fortifications throughout the mountain range, standing out among them the castles of Ares, Ródenas and Alba, which controlled the access roads from Castile and had a leading role during the War of the two Pedros between 1356 and 1369. The basic layout of the Peracense castle that has reached to this day was built in the 14th century [Guitart Aparicio 1999]. It was carried out, like the elements of the first precinct, with ashlars and masonry of material extracted from the 
same rock on which it stands, which gives it its characteristic reddish color and causes its mimicry with the environment and visual camouflage from a certain distance.

A discontinuous wall that disappears in the sections where the slope of the terrain and the presence of large rocks makes it unnecessary closes the second precinct. This perimeter is reinforced by two rectangular towers that protect a small building attached to the wall and roofed with a ribbed vault through which access is granted.

A zigzagging ramp provides access to the outer precinct, which allows a direct entrance to the lower bailey, located on the lowest level of the terrain. The wall that closes it completes sections of the second and extends the fortress to the West; three rectangular towers remain, located in the joints of the various stages of development of the walls and at the western end of the extension.

Of the buildings that formed the castle few remain, but it is possible to affirm the use of structures with diaphragm arches by the presence of some of them, without their corresponding roof, on the cistern, and pointed barrel vaults reinforced by arches. The walls were built entirely with ashlar masonry of 'rodeno' stone.

The whole is an irregular and organic complex, adapted to the irregularities of the terrain as befits a ridge castle developed in various phases, by different lords and kingdoms, and with a fundamental function of control of the territory.

Once it lost its usefulness as a control point in the border with Castile, it was handed over to the Comunidad de Aldeas de Daroca which transformed it into a prison; during the Carlist Wars it was used by both sides alternately and was subsequently abandoned. Since 1987, several archaeological campaigns and restorations of the complex have been carried out, including repristinations of complete sections of the walls.

\section{Other case studies in the border between Castile and Aragon (Spain)}

The territorial boundaries between Aragon and Castile suffered constant war situations throughout the 14th century, so from both sides new fortresses were built and those existing were improved following the same model. They were generally based on earlier elements, as detailed in the case of Peracense, reinforcing what was built or eliminating it in cases of poor construction or state of conservation to maintain the previous position. The poor development of war techniques and theories during the medieval period, before the Renaissance, did not change for centuries the needs to be met by the location of the towers or castles.

On the Castilian side, the cases of the castles of Zafra and Molina de Aragón, both in the present province of Guadalajara, are noteworthy. Starting from towers of Islamic origin, these fortresses were developed with various rings that surrounded the previous elements with a system of organic growth adapted to the relief of the hills on which they stand.

Fig. 4. View of the castle of

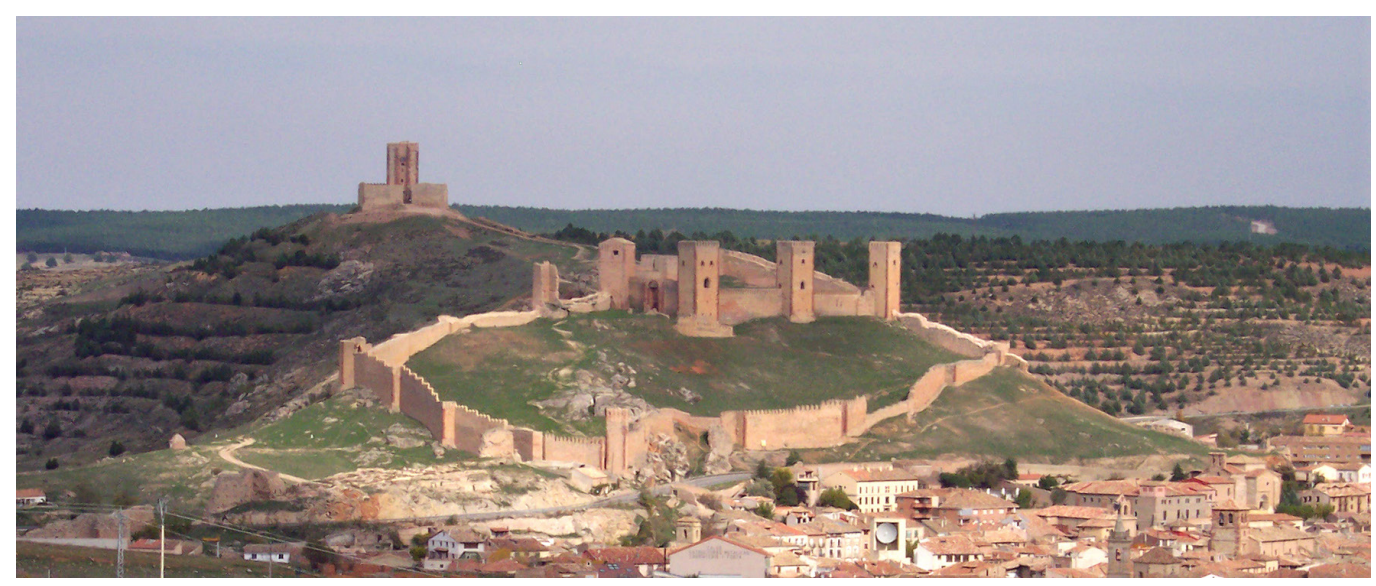


The castle of Molina de Aragón stands out for the large dimensions of the outer precinct, with an approximate perimeter of 800 meters, which extends along the slope of the hill towards the town that is located at its feet. It had five access doors and eight rectangular towers as reinforcement of the walls [Herrera Casado 1999]. As in the case of Peracense, entire sections of the walls have been repristinated, allowing for the understanding of the complex as a whole.

The castle of Zafra is located in the Sierra de Caldereros, in the extension to the West of the Sierra Menera, so it has geological and topographical conditions very similar to this one. Smaller in size than the Peracense castle, the castle of Zafra stands on a large rodeno rock that emerges on a small hill. Developed starting from an initial tower at the northern end, a wall that extends towards the South, enclosing a small bailey with a large and square tower, was added later. The appearance of this castle can become indistinguishable from that of Peracense, nestled on similar rocks and built with the same construction techniques and materials.

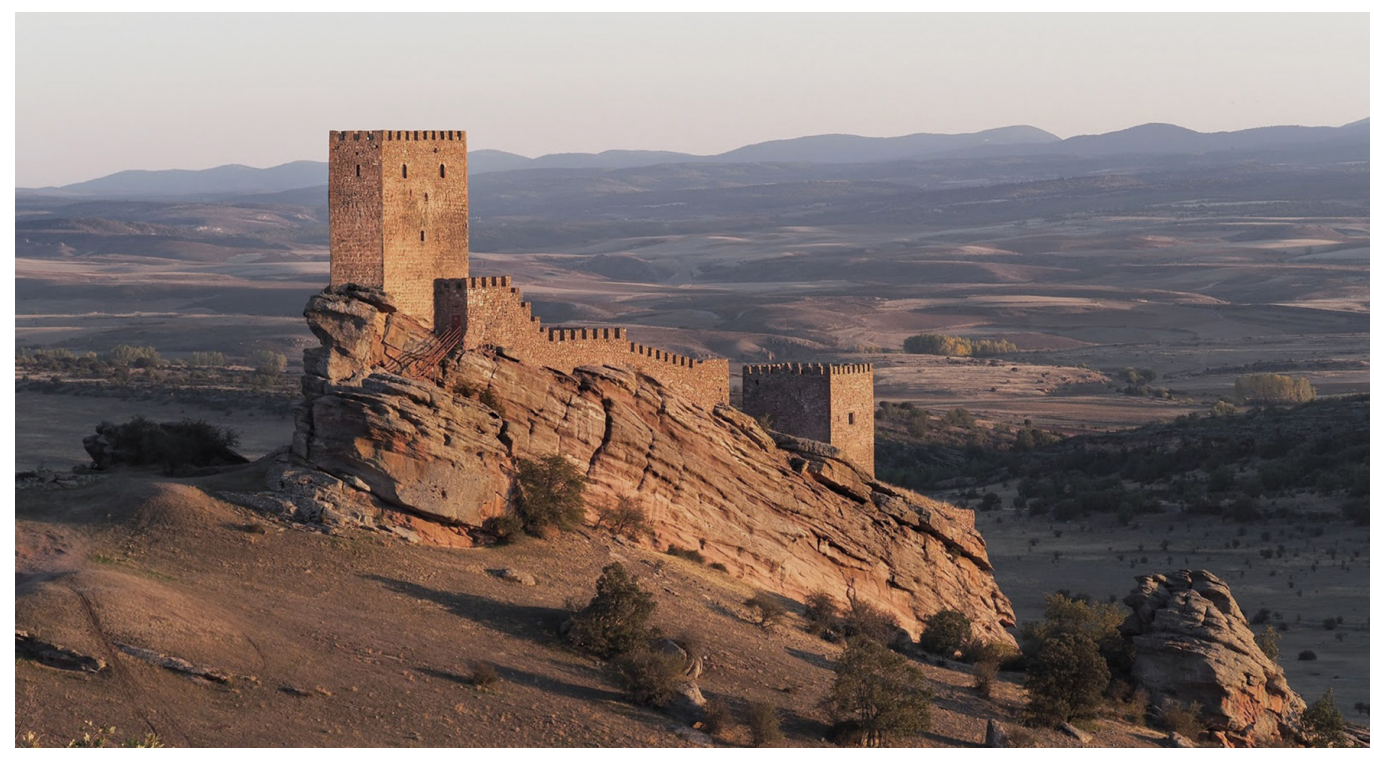

\section{The Aljafería palace (Aragon, Spain)}

The Aljafería palace starts from an Islamic tower of the 9th century and its gradual extensions to serve as the residence of the kings of the Taifa of Zaragoza until the I2th century. After the Christian conquest of the city by Alfonso I the Battler in III8, it became the residence of the kings of Aragon and suffered successive interventions and extensions, the most important being those executed under the reign of Peter IV the Ceremonious and the Catholic Monarchs.

Attached to the northwest wall, Pedro IV built the chapel of San Martín between I 338 and 1339, using traditional structural systems with ribbed vaults, and concluded the western wing of the Santa Isabel patio with multilobulate pointed arches.

The greatest technical finding of this extension is not preserved, but it meant the introduction of the tiled vault in Aragon, being used to cover the space of the new chapel of San Jorge [Zaragozá Catalán, Ibáñez Fernández 20II].

The Catholic Monarchs added a new floor to the northern section of the palace that is accessed via a monumental staircase, mixing Islamic-inspired decorative motifs with grote- 


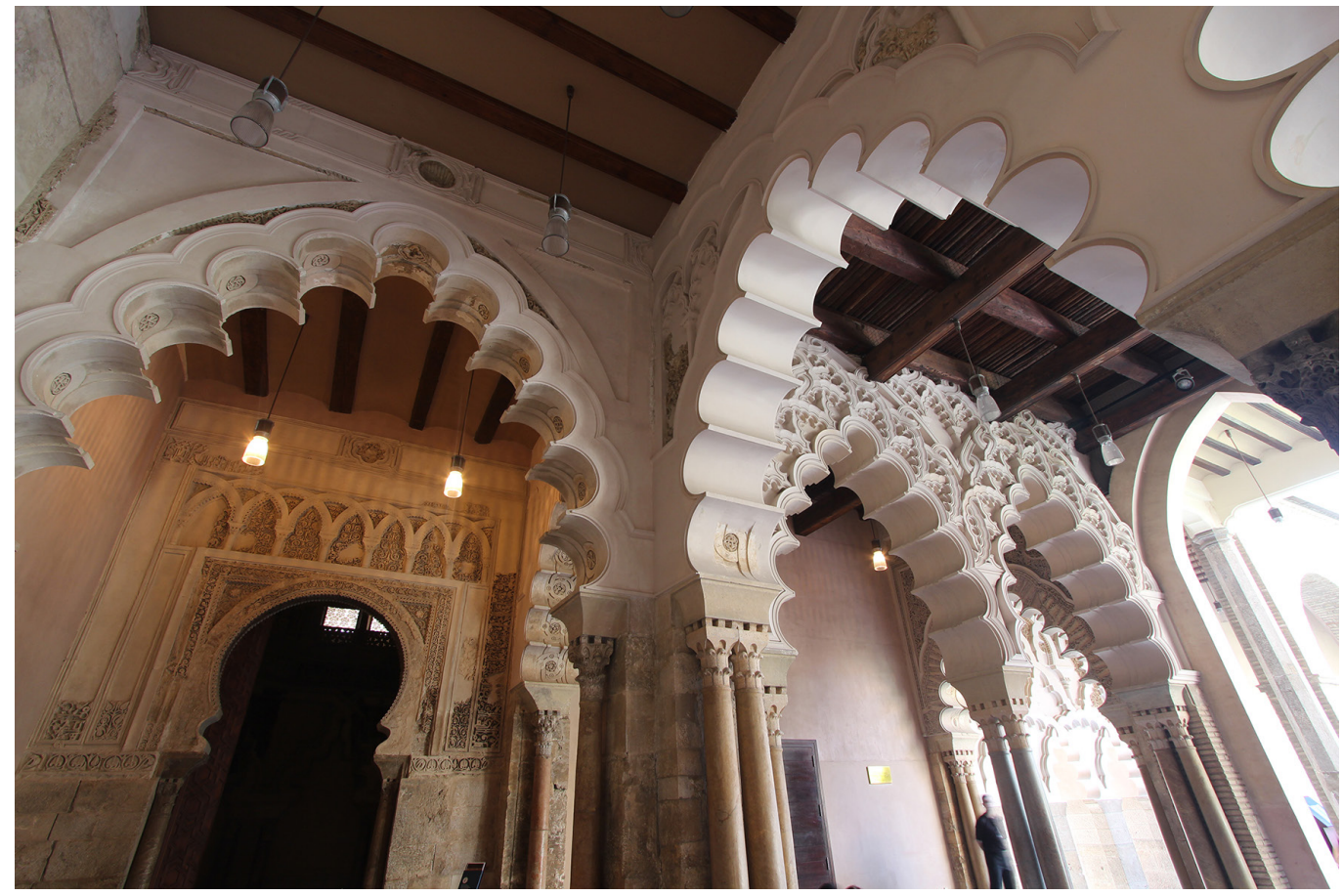

sques and a delicate 'artesonado' in the Throne Hall that herald the arrival of the Renaissance. The last phases reproduce the designs made by Tiburzio Spannocchi for its adaptation to the new artillery systems that he never carried out; these extensions were added very later in time and carried out with a historicist eagerness.

As a whole, a mixture of royal residence and castle that combines the organizational and decorative characteristics of the Islamic world with the medieval Christian and the beginnings of the Renaissance.

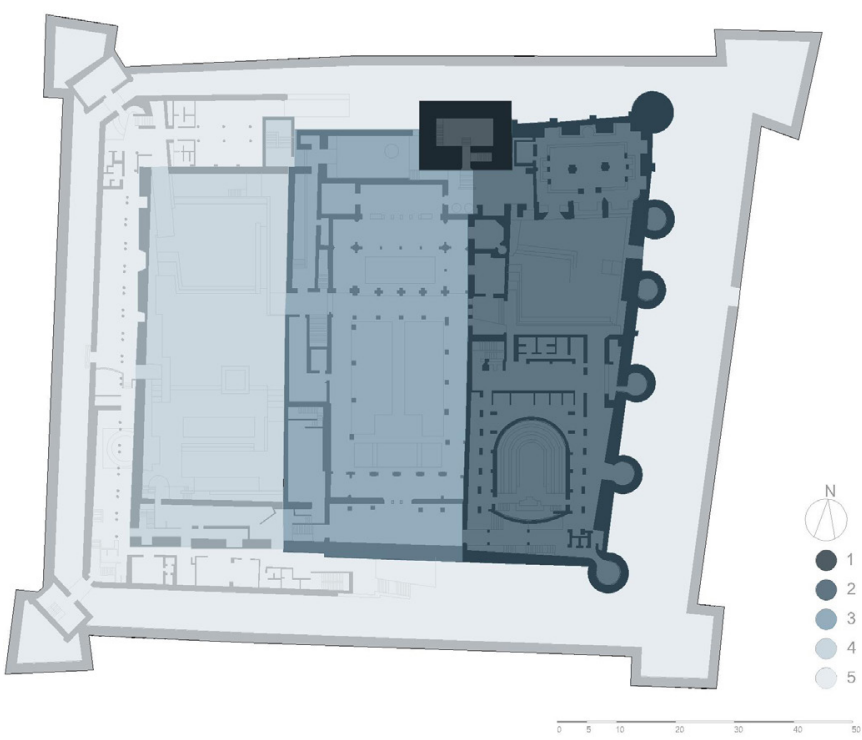




\section{Castel Lagopesole (Basilicata, Italy)}

The case of Castel Lagopesole has great similarities with that of the Aljafería palace in terms of its origin and development. Some theories place the origin of the castle in a fortress of Islamic foundation [Peduto, Santoro 2006], but the oldest remains that are preserved correspond to some structures, discovered in different archaeological excavations, belonging to a small fortress of the I Oth and I I th centuries when the area belonged to the Lombard Principality of Salerno [Fiorillo $20 \mathrm{I}$ I], and to the keep of Norman times. The impetus for the construction of the current castle is of the period of Frederick II, in which the walled space was expanded [lorio 2007], although little is known about the elements that made up the fortress during this phase.

The current configuration of the castle is due to the works of the Angevin period, between the 13th and 14th centuries [Rescio 1998]. The shape of the complex is rectangular (approximately $94 \times 53$ meters), reinforced by square towers in the corners, two towers protecting the main entrance and one more that shows the apse of the chapel to the outside. The walls are straight, uniformly high throughout the enclosure and with no battlement at the top, confirming its function halfway between castle and royal residence.

Inside there are two baileys, corresponding to two consecutive construction phases. The first and smaller one houses the Norman tower, exempt and misaligned with the rest of the construction, and outbuildings on one of its sides; the second one houses the open staircase

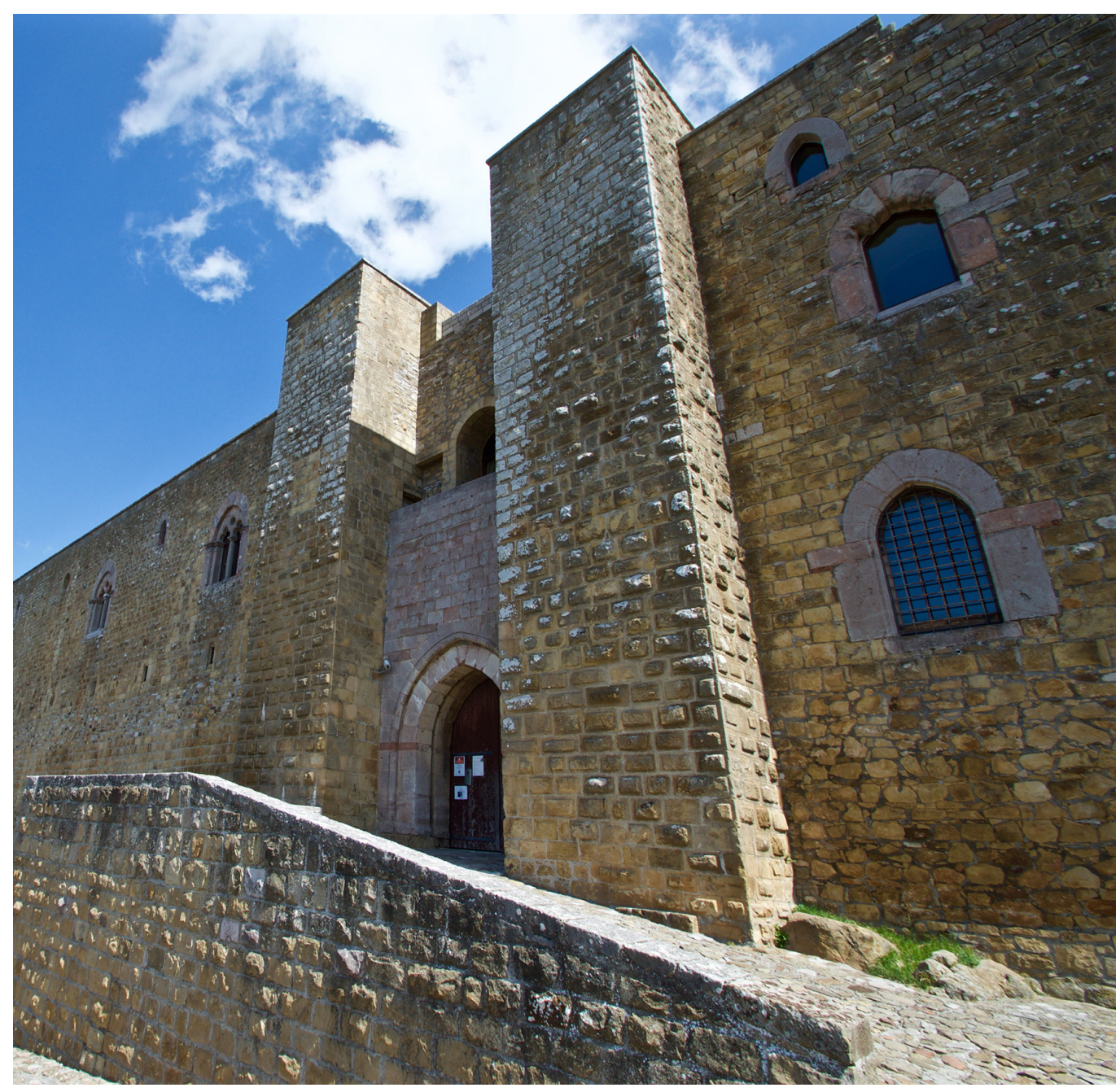


to access the upper floor, the entrance to the chapel and different rooms on the three outer sides. The last element added to the complex, in Aragonese times, is the sloped wall beneath the northwest tower, subsequently interrupting the adaptation of the whole to become a fortress 'a la moderna'.

The filling of the moat that surrounded the castle and the extraction of stone for construction in the 20th century distort the image showed by the whole today.

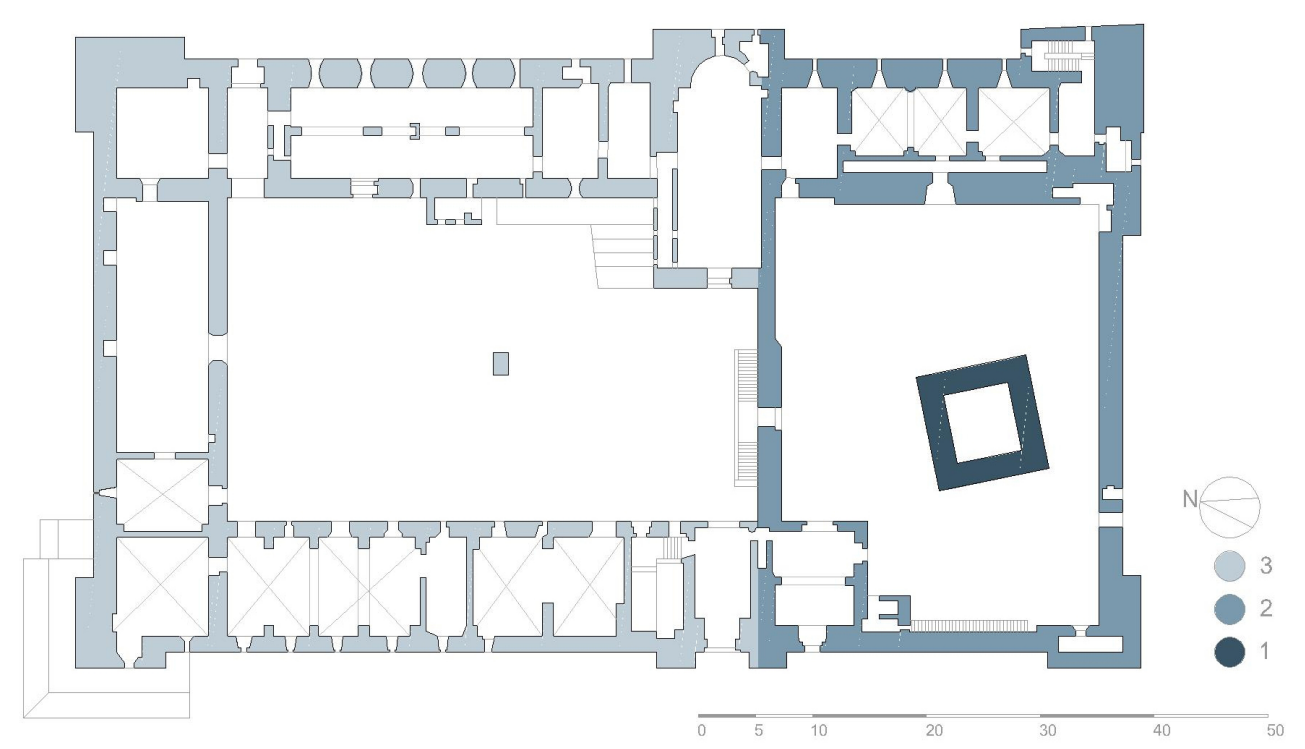

\section{Other case studies in the Italian territories of the Crown of Aragon}

The very origin and development process of Castel Lagopesole characterizes multiple fortresses in southern Italy. Paradigmatic is the case of the Ducale castle of Ceglie Messapica (Apulia), whose oldest element is the base of the square tower, built by the Normans, on which rise the Angevine and Aragonese expansions of the 13th and I4th centuries, reaching a total height of 34 meters [VV. AA 2006]. The layout of the complex is irregular, adapting to the terrain on which it stands, with the three main corners reinforced by circular towers built with three clearly differentiated floors; a low-rise conical base, a cylindrical central segment separated from the base by a torus, and a coronation that rests on a few corbels. We are faced with a clear example of a fortress of medieval conception and development, typical of the feudal castles of the area, with an elevated or piombante defensive position on the enemy due to the height of the walls and the situation of the complex at the highest point of the town. At a time, the scarce development of artillery still did not require a conception 'a la moderna'.

Similar development followed the castles of Santa Severina (Calabria) and Monte Sant'Angelo (Apulia), adding a final chapter of adaptation to modern poliorcetica, incorporating bastions, moat and posts for the use of firearms. 


\section{Conclusions}

The development of the fortresses in the Spanish and Italian territories of the Crown of Aragon during the 13th, I4th and I5th centuries followed similar trends. In both territories, a common Roman past gave great importance to the urban areas within a highly centralized organization that entered into a crisis in the Middle Ages. This system of towns was atomized by important foreign influences, whether they were Normans or Franks who came to fight against the Islamic invasions or those of the Muslims themselves, present in the Iberian Peninsula for centuries. The elements created by Muslims and Normans for the control of the territory were subsequently used, reformed and expanded following similar criteria and systems, recovering common construction traditions and being later abandoned, when war zones were moved away, or transformed into palatial residences as they lost their military functions.

\section{Notes}

[I] It is a defensive system typical of the era of bladed weapons, consisting of the launching of solid or liquid projectiles (arrows, stones, oil, tar ...) on the assailants; this was only possible from an elevated position, either because of the location of the castle on a hill or mountain, or because of the height of the walls of the fortress.

[2] Defensive system that incorporates gunpowder in order to shoot projectiles with firearms.

\section{References}

Fiorillo Rosa (20 I I). Castel Lagopesole (PZ): l'ammodernamento angioino del castrum normanno. In Paolo Peduto, Alfredo Maria Santoro (a cura di). Archeologia dei castelli nell'Europa angioina (secoli XIII-XV) (Salerno, 2008). Firenze: All'Insegna del Giglio, pp. 26-30.

Guitart Aparicio Cristóbal (1999). Castillos de Aragón. Zaragoza: Caja de Ahorros de la Inmaculada de Aragón.

Herrera Casado Antonio (1999). Guía de Campo de los Castillos de Guadalajara. Guadalajara: Ediciones AACHE.

Iorio Guido (2007). I/ Giglio e la Spada. Istituzioni e strutture militari nel meridione angioino. Rimini: il Cerchio Iniziative Editoriali.

Peduto Paolo, Santoro Alfredo Maria (2006). II castello di Lagopesole in Basilicata: analisi di alcune strutture del castrum altomedievale e della Domus federiciana. In Francovich Riccardo, Valenti Marco (a cura di). Società degli Archeologi Medievalisti Italiani. IV Congresso Nazionale di Archeologia Medievale. Chiusdino 26-30 settembre, 2006. Firenze: All'Insegna del Giglio, pp. $621-626$.

Rescio Pierfrancesco (1998). Archeologia e Storia dei Castelli di Basilicata e Puglia. Potenza: Consiglio Regionale di Basilicata.

W.AA. (2006). Architetture fortificate di età aragonese in Puglia. Capitanata, Terra di Bari e Terra d'Otranto. Bari: Mario Adda editore.

Zaragozá Catalán Arturo, Ibáñez Fernández Javier (20I I). Materiales, técnicas y significados en torno a la arquitectura de la Corona de Aragón en tiempos del Compromiso de Caspe (|4|0-14|2). In Artigrama, n.26, pp. 2 I - 102.

Zueco Giménez Luis (201 I). Castillos de Aragón. Zaragoza: Mira.

\section{Authors}

Ignacio Cabodevilla-Artieda, Universidad de Zaragoza.nca@unizar.es

Luis Agustín Hernández, Universidad de Zaragoza. lagustin@unizar.es

Aurelio Vallespín Muniesa, Universidad de Zaragoza. aureliov@unizar.es

To cite this chapter: Cabodevilla-Artieda Ignacio, Hernández Luis, Vallespín Muniesa Aurelio (2020). La Corona de Aragón en España e Italia. Un modelo común de transformación de torres musulmanas y normandas/The Crown of Aragon in Spain and Italy. A common prototype for the transformation of Islamic and Norman towers. In Arena A., Arena M., Brandolino R.G., Colistra D., Ginex G., Mediati D., Nucifora S., Raffa P. (a cura di). Connettere. Un disegno per annodare e tessere. Atti del $42^{\circ}$ Convegno Internazionale dei Docenti delle Discipline della Rappresentazione/ Connecting. Drawing for weaving relationships. Proceedings of the 42th International Conference of Representation Disciplines Teachers. Milano: FrancoAngeli, pp. 957-974. 